Z. Klin. Chem. Klin. Biochem.

12. Jg. 1974, S. 273-275

\title{
Studies on the Absorption of Pyridostigmine: the Application of a Spectrophotometric Method for the Determination of Pyridostigmine in Plasma
}

\author{
By H. Coper, G. Deyhle and K. Dross \\ Institut für Neuropsychopharmakologie and Institut für Klinische Pharmakologie der Freien Universität Berlin
}

(Eingegangen am 26. November 1973/10. Januar 1974)

\begin{abstract}
A method is described for the quantitative determination of pyridostigmine in blood, based on the principle of ion pair extraction. With the aid of this method it was shown that pyridostigmine is absorbed relatively slowly and irregularly, following its oral application. In order to achieve the same concentration in the blood of rats, the oral dose must be 50 times higher than the intraperitoneal dose. Orientation studies on humans confirmed that the absorption is low and irregular after oral application.
\end{abstract}

Es wird ein Verfahren zur quantitativen Bestimmung von Pyridostigmin im Blut beschrieben, das auf dem Prinzip der Ionenpaarextraktion beruht. Mit dieser Methode konnte festgestellt werden, daß Pyridostigmin nach oraler Gabe relativ gering und unregelmäßig resorbiert wird. Um dieselbe Konzentration im Blut der Ratte zu erreichen, wird bei oraler Gabe eine 50 fach höhere Dosis benötigt als bei intraperitonealer Verabreichung. Orientierende Versuche am Menschen haben die Ergebnisse der geringen und unregelmäßigen Resorption bestätigt.

The therapy of Myasthenia gravis with pyridostigmine (Mestinon) often fails to produce the required result. Even in favourable cases, the effective dosage varies considerably between individuals (1). One reason for this could be a poor and/or irregular intestinal absorption of the pyridostigmine. Little is known so far about the uptake and distribution of this substance in the whole organism. The present work was therefore undertaken to determine the relationship between the pyridostigmine concentration in the blood and the quantity administered orally or intraperitoneally in experimental animals. In addition, the lethal dose was determined for the different modes of application. A method was also developed for the quantitative determination of pyridostigmine in plasma.

Pyridostigmine is a quaternary ammonium base, which can be transferred to organic solvents from aqueous solution as an ion pair with the aid of hexanitrodiphenylamine (dipicrylamine). The ion pair can then be dissociated by shaking the organic phase with diluted hydrochloric acid, whereby the pyridostigmine is transferred to the aqueous phase, being finally purified, isolated and identified by chromatography $(3,4)$. This rather laborious and time consuming procedure can be avoided by following the acid treatment with an ion pair extraction of the amine with $\mathrm{I}_{3}$. The resulting $\mathrm{I}_{9}$-complex in the organic phase possesses two typical absorption maxima at 365 and $293 \mathrm{~nm}$, which can be measured directly in a spectrophotometer (5).
The determination procedure can be summarized as follows:

1. Pyridostigmine is mixed with dipicrylamine in a neutral buffer. The resulting stable ion pair is extracted with dichloromethane.

2. The dichloromethane phase is evaporated to dryness, the ion pair cleaved with $\mathrm{HCl}$ and the dipicrylamine removed by extraction again with dichloromethane.

3. The iodine complex of pyridostigmine is formed with the aid of $\mathrm{KI}_{3}$. This complex is extracted with dichloromethane, and determined spectrophotometrically by measuring the absorbance at 293,329 and $365 \mathrm{~nm}$.

\section{Materials and Methods}

Reagents

1. Mestinon (solid pure substance) from Hoffmann-La Roche ${ }^{1}$ )

2. Dipicrylamine (moistened with an equal part of water) p.a. Merck 3089

3. Sodium dihydrogen phosphate 1-hydrate p. a. $\left(\mathrm{NaH}_{2} \mathrm{PO}_{4}\right.$. $\mathrm{H}_{2} \mathrm{O}$ ) Merck 6346

4. Sodium hydroxide flakes, reinst. p. a. Merck 6498

5. Iodine doubly sublimed p. a. Merck 4761

6. Potassium iodide neutral p. a. Merck 5043

7. Sodium sulphate, anhydrous p. a. Merck 6649

8. Dichloromethane p. a. Merck 6050 , distilled

9. Heparin (solid substance) Hoffmann-La Roche ${ }^{1}$ )

1) Mestinon and heparin were generous gifts from HoffmannLa Roche. 
Sulutlons

1. Dipicrylumine solution $10 \mathrm{mmol} / \mathrm{l}: \mathbf{4 4 0} \mathrm{mg}$ dipicrylamino aro dissolvod in $8 \mathrm{nil} 1 \mathrm{~mol} / \mathrm{l} \mathrm{NaOH} ; 20 \mathrm{ml} 0.5 \mathrm{~mol} / \mathrm{l}$ $\mathrm{NaHl}_{2} \mathrm{PO}_{4}$ are added and the volume is adjusted to $50.0 \mathrm{ml}$ with distilled wator. The pH of this solution is 7.0-7.15.

2. Lodino solution.

15.7 g lodine and $20.0 \mathrm{~g} \mathrm{Kl}$ are dissolvad in $100.0 \mathrm{ml}$ distilled wator and shaken mechanically for $\mathbf{4 0} \mathrm{min}$. This solution is stublo indefinitcly at $4^{\circ} \mathrm{C}(2)$. The stock solution is diluted 1:10 with wuter. This solution is stable for about 3 weeks.

lixporiniental unimals

The experimontal anintals were fomale ulbino rats, wistar strain, froin the Hoffim:un animal breeding finm, Berlin. They weighod $180-220 \mathrm{~g}$, and received water and Altroinin R 10 dry food ad libilumi.

\section{Delermination of pyridostigmine}

Rats were docapitated and their blond collected in centrifuge lubus containing a smiall amount of heparin (solid substanca). Alier centrifugation at $3,000 \mathrm{rpm}, 3$ nil of the supernatant plasmin were used for the determination.

\section{Analj'ricul merhod}

1. $3 \mathrm{ml}$ plasmu are mixed with $1 \mathrm{ml}$ dipicrylanino solution (10 mmol/l), followed by $25 \mathrm{~m} /$ dichloromethanc, and the mixture, in a gluss stoppered contrifuge tube, is shaken vertically on " mechanical shaker for $30 \mathrm{~min}$ at $20 \mathrm{rpm}$. Alter 10 min centrifugation at $1,500 \mathrm{rpm}, 20 \mathrm{ml}$ of tho dichloromethane phase are reniovad. The most favourable extriction of the pyridostigmine complex from the plasma into the organic phuse occurs at pH 7.2. The extraction yicld from rat plasmil or whole blond is $93 \%$, as determined in serial exporinents in which pure pyridostigmine was determined with or willout prior extraction. Variations in the ratio of volumes of dipicrylamine solution and djchloromellanno, in the concentration and quantity of Jipicrylamine, or in the shanking time offored no advantagos. The rosults ivere not improved by doproteinization of the rat blood, by ncid precipitution, or boiling.

2. The dichloromethmo phase $(20 \mathrm{mll})$, in a ground glass centrifuge tubs, is evaporated to dryness in a stream of air. The residue can be stored overnight in the rofrigerator ivithout loss. It is dissolved in $0.5 \mathrm{ml} 0.05 \mathrm{~mol} / \mathrm{l} \mathrm{HCl}$ and the resichanl dipicrylumino, which is still prosont at this stago, is removet hy washling first with $6 \mathrm{ml}$, llon with $3 \mathrm{ml}$ dichloronothnne.

3. The sulueous phase is mixed with $20 \mu / \mathrm{KJ}_{3}$ solution plus $3 \mathrm{ml}$ dichloromolhane, thou shaken for $10 \mathrm{~min}$ at $40 \mathrm{rpm}$. Alter contrifugntion to separate the plases, llie organic phuse is transferred to a glass stoppored tube contuining $10 \mathrm{mg}$ anhydrous sodium sulphate. The solution is cuntrifugod and its absorbance meusured at 293, 329 and $365 \mathrm{~nm}$ agn inst dicliloromethanc. The quantity of pyridostigmine eun be dotermined from the difference in the absorbunce at 293 and 329, or 293 and 365 nm (Fig. 1U), using n calibration curve preparod with pure matcrial in $3 \mathrm{ml}$ of plasinn from $\mathrm{mu}$ untrented animal. In the concenturtion range encountered in the animul experiments and in humans, i. c. $0.5-5 \mu \mathrm{g} / 3 \mathrm{ml}$ plasma, the individunl calibmtion values show a scutter of $10-20 \%$ around the average.

Proliminary investigntion of the method showed that light causes a linear decreaso in tho extinction aft or the addition of the $\mathrm{KI}_{3}$ solution. The spectrum also shows qualitative and quantitntive changos (Fig. 1, a and b). After shaking, nll the smmplos must theretore be stored in the dark.

Choline occurs naturally in plasinn and it is precipitated from agueous solution with $l_{j}^{-}(2)$, but it doos not interfere because, unlike pyridostignino, it cannot to extracted as its $I_{9}^{-}$complex with dichloromethunc or chloroform (5). Erroncous results can be obtnined, however, whon other pharmaceutical com. pounds are administored at the sume timo (unpublished results). Under the above conditions, the lower limit for the determination of pyridostignine is $0.3 \mathrm{\mu g} / 3 \mathrm{mll}$ plasma.

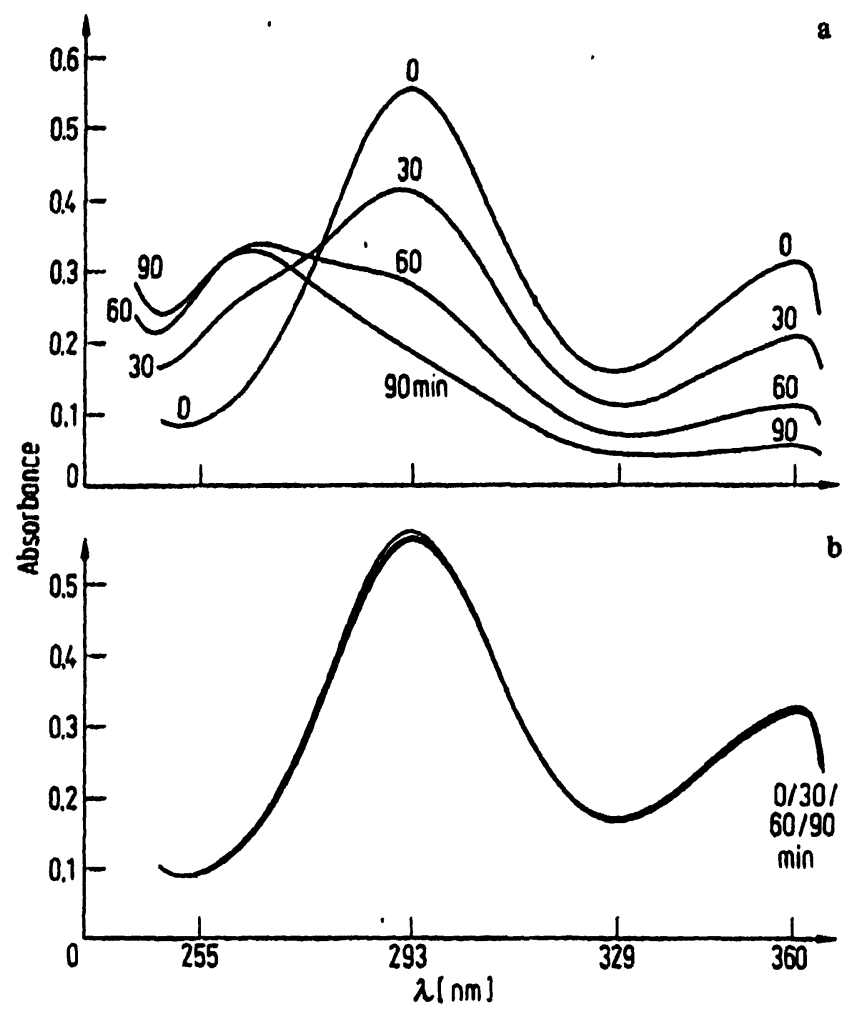

Fig. 1. Alturution with time of the UV absorption of the iodine conplex of pyridostigmine with $\mathrm{KI}_{3}$ in dichloromethane, a) in the light b) in the dark.

\section{Application of pyridostigm inc}

In the first series of oxperiments, the relationship botween the dose and tho plasma concentration was determined at an arbitrarily fixed timo after application. The pyridostigmine was administored in $1 \mathrm{ml}$ aqueous solution per $100 \mathrm{~g}$ animal body woight. The rats wore killed 5 min aftor the intraperitoneal injection of $1,2,3$ and $4 \mathrm{mg} / \mathrm{kg}$ and $15 \mathrm{~min}$ after the oral application of $50,70,90$ and $110 \mathrm{mg} / \mathrm{kg}$.

In the sccond series of experiments, the animals received $2 \mathrm{mg}$ pyridostigmino per $\mathrm{kg}$ body wcight i. p. (1 $\mathrm{ml}$ aqueous solution/ $100 \mathrm{~g})$. Decapitation was 5, 10, 15, 20,30 and $40 \mathrm{~min}$ after the application. For comparison, anothor group of rats reccived $50 \mathrm{mig}$ pyridostigmine per $\mathrm{kg}$ orally, again in $1 \mathrm{ml}$ per $100 \mathrm{~g}$. Thuse animals wero killed 30,60, 120,180 and $240 \mathrm{~min}$ after the application.

\section{Results}

The $L D_{s 0}$ for pyridostigmine after i. p. injection in rats is $3 \mathrm{mg} / \mathrm{kg}$. A concentration range of $1-10 \mathrm{mg} / \mathrm{kg}$ was tested on 5 groups, each containing 6 rats, and the result was calculated according to Kärber (6). After oral application, however, the $L D_{50}$ is $115 \mathrm{mg} / \mathrm{kg}$ ( 7 values, each determined on 6 rats for the range $10-180 \mathrm{mg} / \mathrm{kg}$ ), with considerable scatter. This value alone indicates that the intestinal absorption is low; this is confirmed by experiments in which the pyridostigmine concentration in the plasma was determined after oral and i. p. application. Figure 2 shows that after the i. p. application of $1-4 \mathrm{mg} / \mathrm{kg}$, the concentration of pyridostigmine in the plasma shows a relatively steep and linear increase. After oral dosage, however, the ratio, dose : plasma concentration, is much flatter. Thus, for the same plasma 
concentration, the dose ratio for intraperitoneal : oral is about $1: 55$.

Pyridostigmine appears rapidly in the blood and reaches a maximum concentration in the plasma $5 \mathrm{~min}$ after

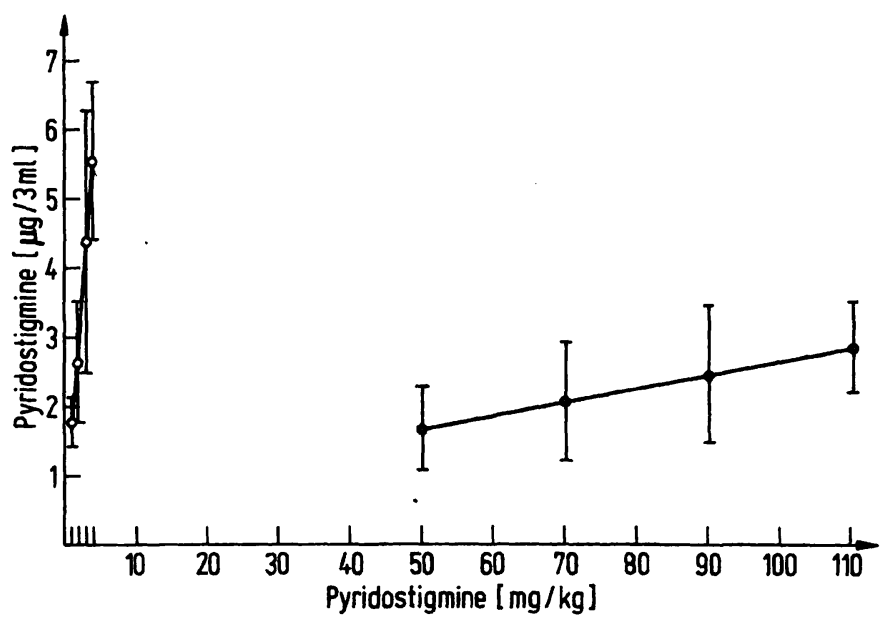

Fig. 2. Dose versus plasma concentration of pyridostigmine for intraperitoneal $(0-05 \mathrm{~min}$ after $1-4 \mathrm{mg} / \mathrm{kg}$ ) and oral $(\bullet-15 \mathrm{~min}$ after $50-110 \mathrm{mg} / \mathrm{kg}$ ) application. Each point represents the average $( \pm s)$ from 4-7 animals.

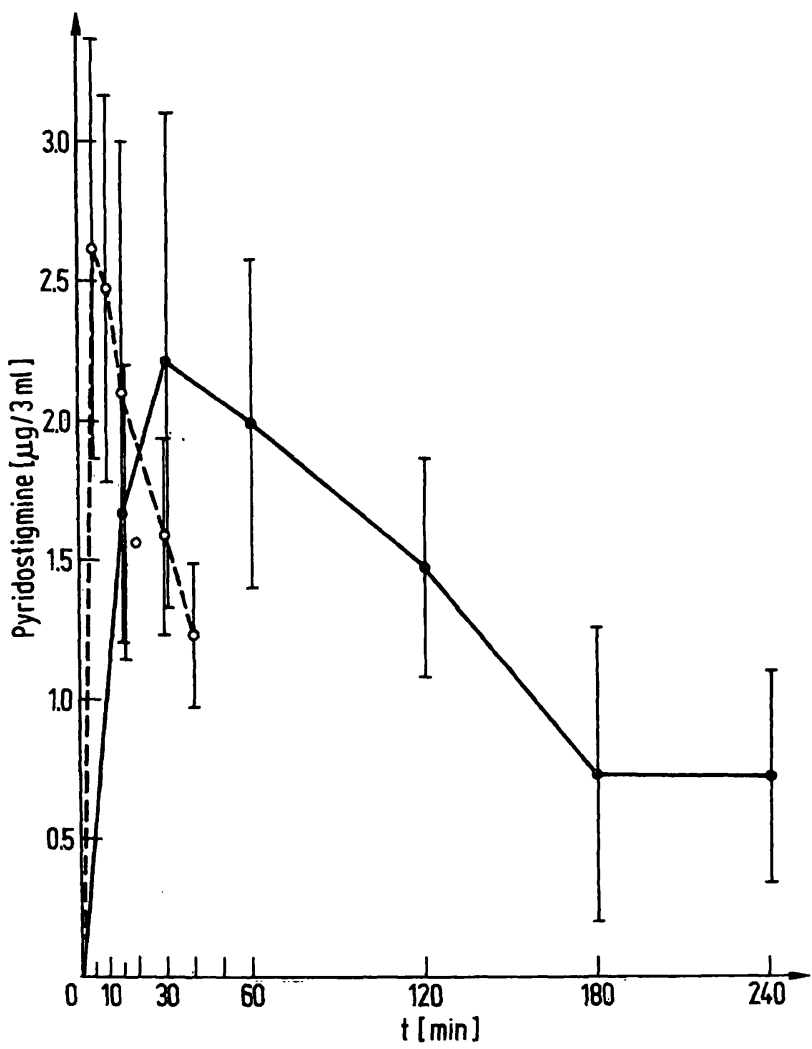

Fig. 3. Comparison of the plasma concentrations of pyridostig mine in the rat after intraperitoneal $(0--0,2 \mathrm{mg} / \mathrm{kg})$ and oral $(\bullet-50 \mathrm{mg} / \mathrm{kg})$ application. Each point represents the average $( \pm \mathrm{s})$ from 10-11 animals. i. p. application (Fig. 3). Absorption from the peritoneal cavity is therefore very rapid. For the concentration range used in these experiments, the half life of the elimination, starting from the maximum, is $28 \mathrm{~min}$. In contrast, it takes 30 min to attain the maximal concentration after oral application. At this time, the absorption is probably still incomplete, for, as shown in Figure 3, the subsequent elimination occurs much more slowly. Plasma pyridostigmine concentrations above $2 \mu \mathrm{g} / 3 \mathrm{ml}$ give rise to easily recognizable muscular convulsions, shivering and chromodacryorrhea, etc. After an i. p. application of $2 \mathrm{mg} / \mathrm{kg}$, these symptoms become apparent within the first $5 \mathrm{~min}$, and they have largely died away after $15-20 \mathrm{~min}$. After $50 \mathrm{mg} / \mathrm{kg}$ orally, however, these symptoms do not appear for 20-30 min, after which they continue for further $30 \mathrm{~min}$. Investigations on humans principally confirmed that the absorption is low and irregular after oral application. This is demonstrated in Figure 4 for four patients who received $120 \mathrm{mg}$ pyridostigmine in the form of Mestinon dragees. Since the determination method is not sensitive below $0.5 \mu \mathrm{g} / 3 \mathrm{ml}$ and the scatter in this part of the calibration curve is greater than $20 \%$, it is not known if absorption occured during the first hour in patients S. L. and E. J.

A detailed study of the relationship between the serum concentration of pyridostigmine and its therapeutic effect, or its possible toxic action will be published elsewhere.

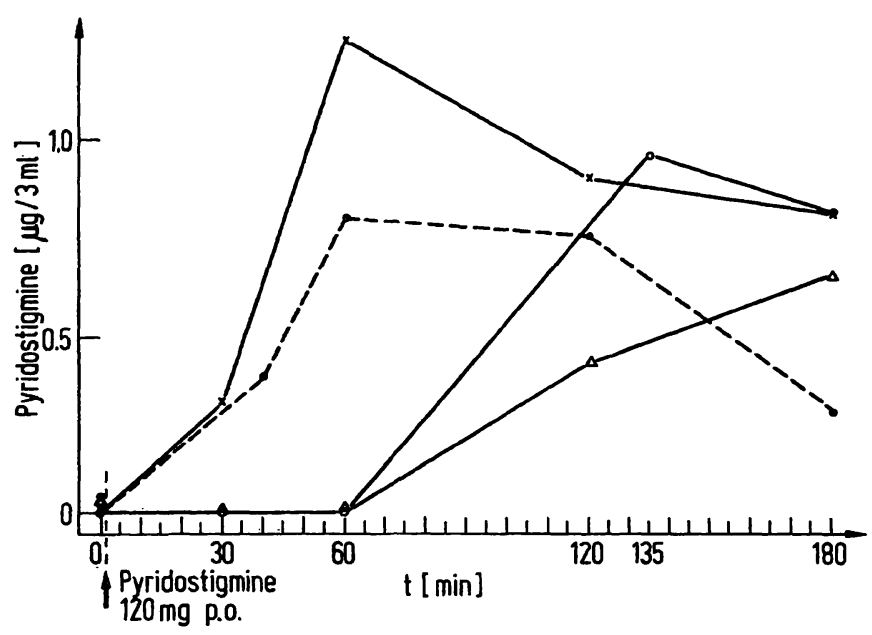

Fig. 4. Behaviour of the pyridostigmine concentration in the serum of patients after the oral application of $120 \mathrm{mg}$ Mestinon.

$X-X$ E. T.

$\bullet-\cdots$ J. F.

$\triangle \longrightarrow$ S. L.

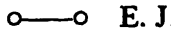

\section{Literatur}

1. Wolter, M., (1971), Deut. Med. J. 22, 417-419.

2. Appleton, H. D., La Du, B. N., Levy, B. B., Steele, J. M. \& Brodie, B. B. (1953); J. Biol. Chem. 205, 803-813.

3. Klöppel, A., Post, D., Schneider, G. \& Schütz, H. (1970), Z. Anal. Chem. 252, 279-284.

4. Schill, G. \& Danielsson, B. (1959), Anal. Chim. Acta 21, 248-254.

5. Vidic, H. J., Dross, K. \& Kewitz, H. (1972), this j. 10, 156-159.

6. Kärber, G. (1931), Naunyn-Schmiedebergs Arch. Pharmakol. Exp. Pathol. 162, 480-483.

Prof. Dr. H. Coper 1000 Berlin 19 Ulmenallee 30 